\title{
Silicone Macromers for Graft Polymer Synthesis
}

\author{
Yuhsuke KAWAKAMI,* Yoshiaki MIKI, Takashi TsUDA, \\ R. A. N. MURThY, and Yuya Yamashita \\ Department of Synthetic Chemistry, Faculty of Engineering, \\ Nagoya University, Chikusa, Nagoya 464, Japan
}

(Received April 22, 1982)

\begin{abstract}
KEY WORDS Macromer / Graft Polymer / Silicone / Chlorosilane / Hydrosilylation /
\end{abstract}

Silicone polymers are industrially produced in large quantity for various purposes depending molecular weight and copolymer composition. Silicones are also noteworthy for their high permeability of gases. However, their thin films are not mechanically strong enough for use as gas permeable membranes. The disadvantage has been overcome by making thin films of block polymers with polycarbonates with excellent results. ${ }^{1}$ It would be of interest to synthesize silicone containing graft polymers having hard backbone seg- ments from the standpoint of mechanically strong gas permeable membranes of phase separated structures.

Although there are many methods for preparing graft polymers, the macromer method seems advantageous since the number and length of the grafted branches can be easily controlled. In doing this, two types of silicone macromers, namely styrene and methacrylate types, were synthesized according to Scheme 1.

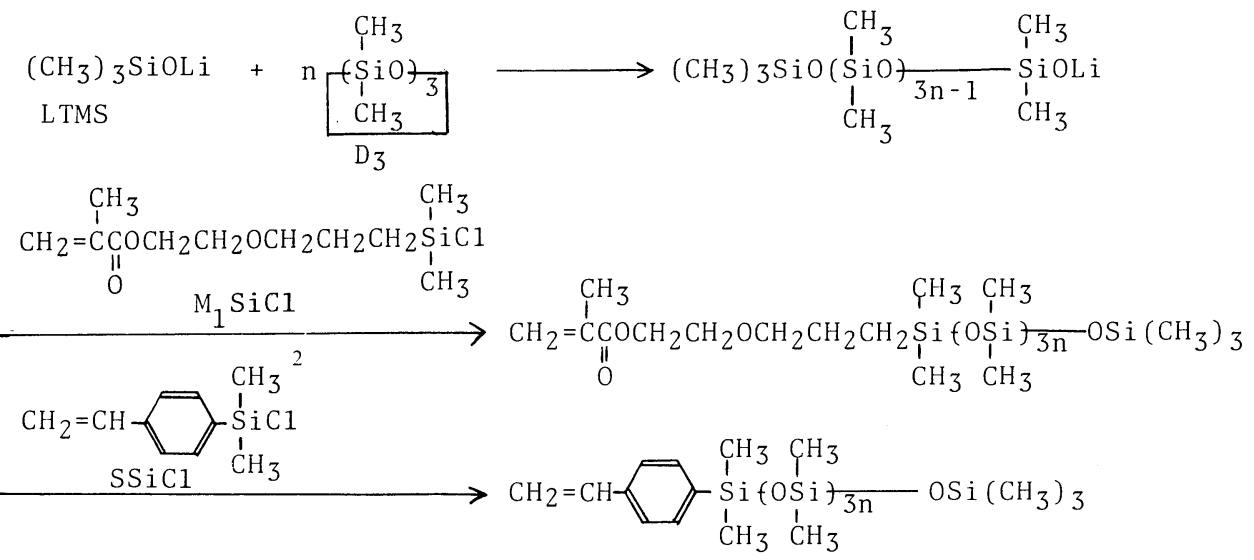

Scheme 1. Synthetic scheme of silicone macromers.

The two types of chlorosilane terminating agents

were synthesized according to Scheme 2 .

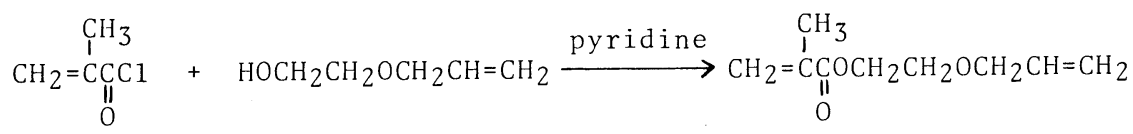




$$
\begin{aligned}
& \text { or } \mathrm{HOCH}_{2} \mathrm{CH}_{2} \mathrm{CH}_{2} \mathrm{CH}=\mathrm{CH}_{2}{ }^{3} \longrightarrow \stackrel{\substack{1 \\
I}}{\mathrm{CH}_{2}}=\stackrel{\mathrm{C}}{\mathrm{C}}-\mathrm{OCH}_{2} \mathrm{CH}_{2} \mathrm{CH}_{2} \mathrm{CH}=\mathrm{CH}_{2}
\end{aligned}
$$

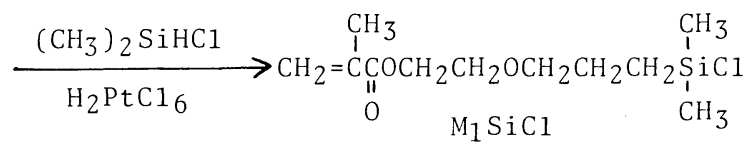

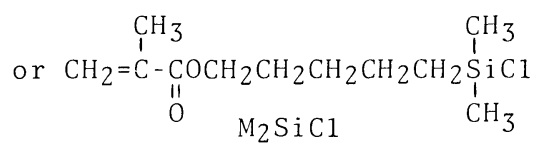

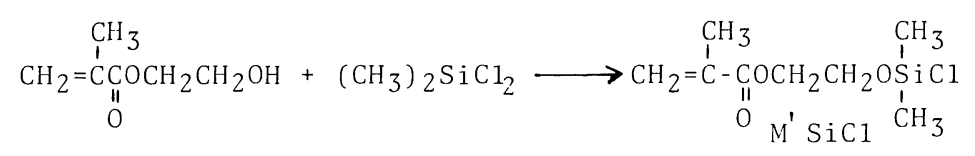

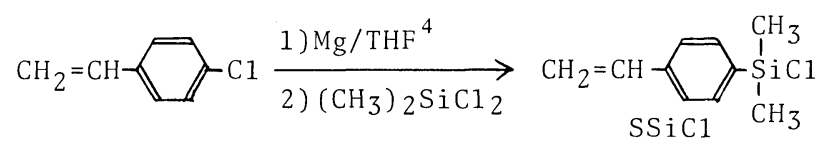

Scheme 2. Synthetic scheme of chlorosilane terminating agents.

These chlorosilane end-capping agents were reacted with lithium trimethylsilanolate (LTMS), as model reactions, to study reactivity toward living ends. It was found that both the end-capping agents reacted instantaneously and quantitatively with LTMS at ambient temperature, as evidenced by ${ }^{1} \mathrm{H}$ NMR.

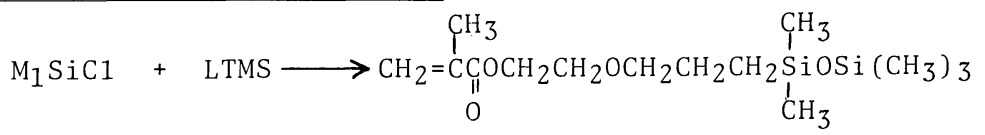

$$
\begin{aligned}
& \mathrm{M}_{1} \text { SiOTMS }
\end{aligned}
$$

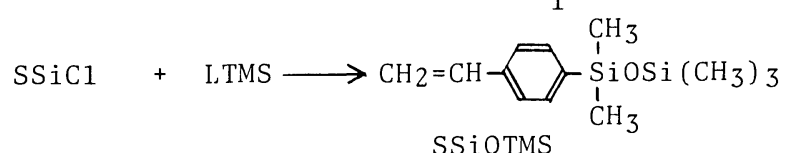

The polymerization of $D_{3}$ was initiated by LTMS and terminated with trimethylsilyl chloride in THF. Polymers of molecular weight as high as 10,000 with narrow molecular weight distributions could be obtained by living anionic polymerization.

Since the degree of polymerization could be controlled by simply changing the monomer initiator ratio, and both the terminating agents reacted quantitatively with LTMS, silicone macromers having specified molecular weights were synthesized by terminating the living polydimethylsiloxane with $\mathrm{SSiCl}$ or $\mathrm{MSiCl}\left(\mathrm{M}_{1} \mathrm{SiCl}\right.$ or $\left.\mathrm{M}_{2} \mathrm{SiCl}\right)$. The results for this are shown in Table I.

In experiments of the $\mathrm{S}$ and $\mathrm{M}$ series, experimental molecular weight values by various methods coincided quite well with those calculated; the molecular weight distribution was considerably narrow. The functionality of macromers estimated by VPO and UV fell in the region 0.97-1.12. Thus, the well defined silicone macromers of styrene and methacrylate type (macro-St and macro-MA) were obtained. But termination by $\mathrm{M}^{\prime} \mathrm{SiCl}$ gave polymers having abnormally high molecular weights as estimated by UV. This implies that the functionality of the macromer is much lower than unity (0.38). The reason for this may possibly be that bonding between the prepolymer and end-capping agent (C-O-Si bond), following its formation is unstable and cleaved in the purification step. The $\mathrm{CH}_{2} \mathrm{OSi}\left(\mathrm{CH}_{3}\right)_{2} \mathrm{O}$ bond is known to 
Silicone Macromers for Graft Polymer Synthesis

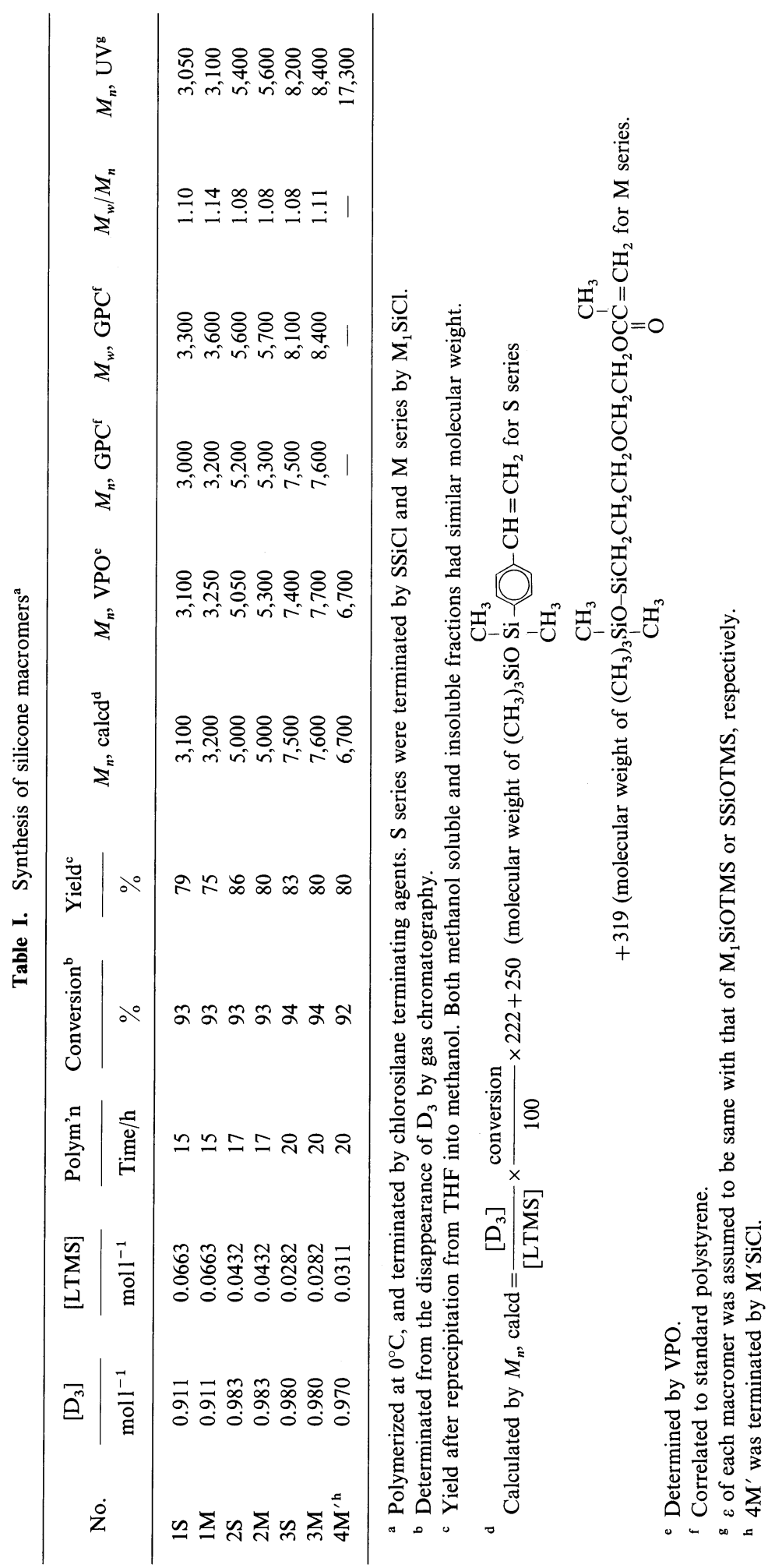


Table II. Copolymerization of macromers

\begin{tabular}{|c|c|c|c|c|c|c|c|c|}
\hline No. & $\frac{\text { Macromer }}{\mathrm{wt} \%}$ & $\frac{\text { Comonomer }}{w \mathrm{w} \%}$ & $\frac{\mathrm{AIBN}}{\mathrm{mol} \%}$ & $\frac{\text { Time }}{\mathrm{h}}$ & $\frac{\text { Yield }}{\%}$ & $\begin{array}{l}\text { Siloxane component in } \\
\text { graft polymer } / \mathrm{wt}^{\circ} \%\end{array}$ & $M_{n}, \mathrm{GPC}^{\mathrm{a}}$ & $M_{n}, \mathrm{mo}^{\mathrm{b}}$ \\
\hline 1 & $\begin{array}{c}\text { Macro-MA } \\
21.1\end{array}$ & $\begin{array}{c}\text { MMA } \\
78.9\end{array}$ & 0.30 & 15 & 76 & 21 & 40,100 & 85,700 \\
\hline 2 & $\begin{array}{c}\text { Macro-St } \\
15.8\end{array}$ & $\begin{array}{c}\mathrm{St} \\
84.2\end{array}$ & 0.33 & 136 & 80 & 15 & 32,000 & 42,900 \\
\hline
\end{tabular}

a Correlated to standard polystyrene.

b Determined by membrane osmometry.

c $\mathrm{M}_{1} \mathrm{SiCl}$ terminated macromer $2 \mathrm{M}$ was used.

d $\mathrm{SSiCl}$ terminated macromer $1 \mathrm{~S}$ was used.

be easily cleaved by hydrolysis.

The macromers, macro-St and macro-MA, were converted into graft polymers by copolymerizing with styrene and methyl methacrylate, respectively, as shown in Table II.

In copolymerization, both macromers showed almost the same reactivity as that of the corresponding monomers. The number of branches was roughly estimated as 3.2 and 2.2 for No. 1 and No. 2, respectively.

\section{EXPERIMENTAL}

\section{3-(2-Methacryloyloxyethoxy)propyldimethylchloro- silane [ $\left.\mathrm{M}_{1} \mathrm{SiCl}\right]$}

To a prewarmed $\left(60^{\circ} \mathrm{C}\right)$ mixture of 2-allyloxyethyl methacrylate $(5.11 \mathrm{~g}, 30 \mathrm{mmol}), p$ - $t$-butylcatechol $(0.10 \mathrm{~g})$ and chloroplatinic acid $\left(\mathrm{H}_{2} \mathrm{PtCl}_{6}\right.$. $\left.6 \mathrm{H}_{2} \mathrm{O}, 0.052 \mathrm{~g}, 0.1 \mathrm{mmol}\right)$ in 2-propanol $(0.5 \mathrm{ml})$ contained in a round bottom flask equipped with a Dewer condenser, dimethylchlorosilane $(3.41 \mathrm{~g}$, $36 \mathrm{mmol}$ ) was added dropwise at a speed sufficient to bring about a gentle reflux of dimethylchlorosilane within a period of $30 \mathrm{~min}$. The reaction mixture heated at the above temperature for an additional $3 \mathrm{~h}$ stirring. The product $\mathrm{M}_{1} \mathrm{SiCl}$ was obtained by distillation directly from the reaction mixture, bp $80^{\circ} \mathrm{C}(0.1 \mathrm{mmHg}), 2.15 \mathrm{~g}(27 \%)$. Calcd for $\mathrm{C}_{11} \mathrm{H}_{21} \mathrm{O}_{3} \mathrm{SiCl}: \mathrm{C}, 49.89 \% ; \mathrm{H}, 7.99 \% ; \mathrm{O}$, $18.12 \%$; Si, $10.61 \%$; Cl, $13.39 \%$, Found: C, $50.15 \%$; $\mathrm{H}, 8.11 \% ; \mathrm{Cl}, 13.08 \% .{ }^{1} \mathrm{H}$ NMR $\left(\mathrm{CDCl}_{3}\right) \delta 0.40(\mathrm{~s}$, $\left.6 \mathrm{H}, \mathrm{Si}\left(\mathrm{C}_{3}\right)_{2}\right), 0.66-1.12\left(\mathrm{~m}, 2 \mathrm{H}, \mathrm{SiC}_{2}\right), 1.40-$ $1.95\left(\mathrm{~m}, 2 \mathrm{H}, \mathrm{CH}_{2}\right), 1.96\left(\mathrm{~m}, 3 \mathrm{H}, \mathrm{CC}_{3}\right), 3.34-3.70$ (m, $\left.4 \mathrm{H}, \mathrm{CH}_{2} \mathrm{OC}_{2}\right), 4.16-4.47\left(\mathrm{~m}, 2 \mathrm{H}, \mathrm{CO}_{2} \mathrm{CH}_{2}\right)$, $5.57(\mathrm{~m}, 1 \mathrm{H}, \mathrm{C} \underline{\mathrm{H}}=)$, and $6.13 \mathrm{ppm}(\mathrm{s}, 1 \mathrm{H}, \mathrm{C} \underline{\mathrm{H}}=)$.

\section{5-Methacryloyloxypentyldimethylchlorosilane [ $\left.\mathrm{M}_{2} \mathrm{SiCl}\right]$}

This compound was synthesized from 4-pentenyl methacrylate in a manner similar to that for obtaining $\mathrm{M}_{1} \mathrm{SiCl}$. bp $92^{\circ} \mathrm{C}(0.9 \mathrm{mmHg}), 75 \%$ yield. Calcd for $\mathrm{C}_{11} \mathrm{H}_{21} \mathrm{O}_{2} \mathrm{SiCl}: \mathrm{C}, 53.10 \% ; \mathrm{H}, 8.50 \% ; \mathrm{O}$, $12.86 \%$; $\mathrm{Si}, 11.29 \%$; Cl, $14.25 \%$. Found: $\mathrm{C}, 53.40 \%$; $\mathrm{H}, 8.72 \%, \mathrm{Cl}, 14.10 \% .{ }^{1} \mathrm{H}$ NMR $\left(\mathrm{CDCl}_{3}\right) \delta 0.38(\mathrm{~s}$, $\left.6 \mathrm{H}, \mathrm{Si}\left(\mathrm{C}_{3}\right)_{2}\right), 0.62-1.02$ (broad, $2 \mathrm{H}, \mathrm{C}_{2} \mathrm{Si}$ ), $1.17-1.83\left(\mathrm{~m}, 6 \mathrm{H},\left(\mathrm{C}_{2}\right)_{3}\right), 1.92\left(\mathrm{~m}, 3 \mathrm{H}, \mathrm{CC}_{3}\right)$, $4.51\left(\mathrm{t}, 2 \mathrm{H}, J=7.0 \mathrm{~Hz}, \mathrm{OC}_{2}\right), 5.60(\mathrm{~m}, 1 \mathrm{H}, \mathrm{C} \underline{\mathrm{H}}=)$, and $6.08 \mathrm{ppm}(\mathrm{m}, 1 \mathrm{H}, \mathrm{C} \underline{\mathrm{H}}=)$.

\section{p-Vinylphenyldimethylchlorosilane ( $\mathrm{SSiCl})$}

$p$-Vinylphenylmagnesium chloride ${ }^{2}(0.2 \mathrm{~mol}$, in $120 \mathrm{ml}$ THF) was added dropwise to dimethyldichlorosilane $(51.7 \mathrm{~g}, 0.4 \mathrm{~mol})$. Following this, the reaction mixture was refluxed for $30 \mathrm{~min}$. Ether $(100 \mathrm{ml})$ was added to the resulting system, and the formed salt was filtered off in a dry-box. The product $\mathrm{SSiCl}$ was obtained directly from the reaction mixture by distillation, $60-65^{\circ} \mathrm{C} \quad(0.5$ $\mathrm{mmHg}), 20 \mathrm{~g}(51 \%)$. bp $63^{\circ} \mathrm{C}(0.01 \mathrm{~mm})$ (lit. 2) 62$63^{\circ} \mathrm{C}(0.01 \mathrm{mmHg}) .{ }^{1} \mathrm{H} \mathrm{NMR}\left(\mathrm{CDCl}_{3}\right) \delta 0.66(\mathrm{~s}, 6 \mathrm{H}$, $\left.\mathrm{Si}\left(\mathrm{CH}_{3}\right)_{2}\right), 5.23\left(\mathrm{q}, 1 \mathrm{H}, J_{1}=2.0 \mathrm{~Hz}, J_{2}=10.0 \mathrm{~Hz}\right.$, H

$$
\begin{aligned}
& \mathrm{C}=\mathrm{C}), 5.88\left(\mathrm{q}, 1 \mathrm{H}, J_{1}=2.0 \mathrm{~Hz}, J_{2}=18.0 \mathrm{~Hz},\right. \\
& \left.\underline{\mathrm{H}}^{\prime}=\mathrm{C}\right), 6.66\left(\mathrm{q}, 1 \mathrm{H}, J_{1}=10.0 \mathrm{~Hz}, J_{2}=18.0 \mathrm{~Hz},\right. \\
& \left.{\mathrm{C}=\mathrm{C}_{\backslash}^{\prime}}^{\prime}{ }^{\mathrm{H}}\right), 7.33(\mathrm{~d}, 2 \mathrm{H}, J=8.0 \mathrm{~Hz},
\end{aligned}
$$


3-(2-Methacryloyloxyethoxy)propylpentamethyldisiloxane ( $M_{1}$ SiOTMS)

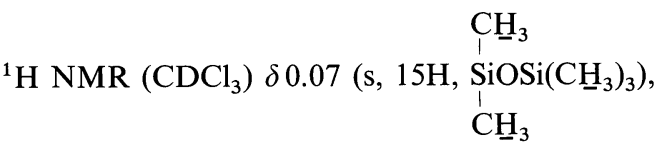

$0.33-0.67\left(\mathrm{~m}, 2 \mathrm{H}, \mathrm{SiC}_{2}\right), 1.00-1.82(\mathrm{~m}, 2 \mathrm{H}$, $\left.\mathrm{CH}_{2}\right), 1.94\left(\mathrm{~m}, 3 \mathrm{H}, \mathrm{CCH}_{3}\right), 3.30-3.80(\mathrm{~m}, 4 \mathrm{H}$, $\left.\mathrm{C}_{2}{ }_{2} \mathrm{OCH}_{2}\right), 4.13-4.30\left(\mathrm{~m}, 2 \mathrm{H}, \mathrm{CO}_{2} \underline{\mathrm{C}}_{2}\right), 5.51(\mathrm{~m}$, $1 \mathrm{H}, \mathrm{C} \underline{\mathrm{H}}=)$, and $6.10 \mathrm{ppm}(\mathrm{s}, 1 \mathrm{H}, \mathrm{C} \underline{\mathrm{H}}=)$.

p-Vinylphenylpentamethyldisiloxane (SSiOTMS)

${ }^{1} \mathrm{H}$ NMR $\left(\mathrm{CDCl}_{3}\right) \delta 0.11\left(\mathrm{~s}, 9 \mathrm{H}, \mathrm{Si}\left(\mathrm{C}_{3}\right)_{3}\right), 0.33$

$\mathrm{C}_{3}$

(s, $\left.6 \mathrm{H},-\mathrm{SiO}_{1}\right), 5.20\left(\mathrm{q}, 1 \mathrm{H}, J_{1}=2.0 \mathrm{~Hz}, J_{2}=10.0 \mathrm{~Hz}\right.$,

H $\mathrm{CH}_{3}$

$\mathrm{C}=\mathrm{C}), 5.80\left(\mathrm{q}, 1 \mathrm{H}, J_{1}=2.0 \mathrm{~Hz}, J_{2}=18.0 \mathrm{~Hz}\right.$, $\underline{H}^{-}$

$\mathrm{C}=\mathrm{C}), 6.66\left(\mathrm{q}, 1 \mathrm{H}, J_{1}=10.0 \mathrm{~Hz}, J_{2}=18.0 \mathrm{~Hz}\right.$,

$\left.\mathrm{C}=\mathrm{C}^{\prime} \stackrel{\stackrel{\mathrm{H}}{2}}{ }\right), 7.30(\mathrm{~d}, 2 \mathrm{H}, J=8.0 \mathrm{~Hz}, \overbrace{\underline{\mathrm{H}}}^{\underline{\mathrm{H}}} \mathrm{Si})$, and

$7.48 \mathrm{ppm}(\mathrm{d}, 2 \mathrm{H}, J=8.0 \mathrm{~Hz}$,<smiles>[SiH2]=CC=C[SiH3]</smiles>

\section{Macromers}

The living polydimethylsiloxanes in Table I were reacted with $10 \%$ excess of $\mathrm{MSiCl}$ or $\mathrm{SSiCl}$ at $-78^{\circ} \mathrm{C}$. The formed macromers were purified by reprecipitation from THF into methanol.

\section{Graft Polymers}

The graft polymers were purified by fractional reprecipitation from THF into ether (M series) or from THF into methanol (S series). The absence of the macromer was evidenced by GPC. The composition of graft polymers was estimated by ${ }^{1} \mathrm{H}$ NMR. The molecular weight was determined by GPC and membrane osmometry. The molecular weight by GPC was considerably lower than that determined by membrane osmometry. Membrane osmometry should provide accurate molecular weight determinations for branched polymers.

\section{REFERENCES}

1. W. J. Ward III, W. R. Browall, and R. M. Salemme, J. Membrane Sci., 1, 99 (1976).

2. Von G. Greber and E. Reese, Makromol. Chem., 55, 96 (1962).

3. M. S. Kharasch and C. F. Fuchs, J. Org. Chem., 9, 359 (1944).

4. J. R. Leebrick and H. E. Ramsden, J. Org. Chem., 23, 935 (1958). 